\title{
Learning Model Of Reflective Inquiry Based On Environment As A Source Of Learning Ips Education
}

\author{
Edi Susrianto Indra Putra, Ahmad, Khairuddin, Hasnawati, Ferdinan
}

\begin{abstract}
Social Sciences Education (IPS) is very closely related to factual issues that occur in the midst of society. Because social studies learning material is very closely related to social values and national cultural values. One of the characteristics of social studies education is the development of values, value analysis and its application in social action. Social issues can be defined as problems that occur in the midst of society that have not been resolved and invite the attention of the community as citizens. In solving social problems, Social Studies Education must take an active role. One approach that can be used to solve this social problem is through the reflective inquiry approach. Through the reflective inquiry approach, students are taught how to use social skills to solve factual problems that occur in daily life in the midst of society. Social studies education must be able to help students control themselves in life and apply these values in their behavior in the midst of society. Social studies education must be able to develop the community into a good citizen, familiar with all elements of the environment, be wise and wise in fostering relationships, exploring, and developing various forms of elements of the existing cultural environment.
\end{abstract}

Keywords : Learning Model, Reflective Inquiry, and Social Studies Education.

\section{INTRODUCTION}

Social Sciences Education (IPS) in Indonesia has been known since the 1960s. This idea was greatly influenced by social studies in the United States. The term social studies used in the United States aims to give names or subjects in schools that provide social or community education whose material comes from the social sciences and humanities that are organized in an integrated manner for the development of abilities as citizens. The National Council for Social Studies (NCSS) provides the following definitions of social studies, Social studies is the integrated study of social sciences and humanities to promote civic competence. Within the school program, social studies provides coordinate, systematic study drawing upon disciplines as anthropology, archaelogy, economics, geography, history, law, philosophy, political science, psychology, religion, and sociology, as well as appropriate content from the humanities, mathematics, and natural sciences. The primary purpose of social studies is to help young people develop the ability to make informed and reasoned decisions for the public good as citizens of culturally diverse, democratic society in an interdependent world [1]. Based on the definition above, it can be said that the scope of social studies is very broad. The material is not only taken from the social sciences, but also from the cultural sciences, philosophy, religion, natural sciences, and mathematics. The material from various fields of science is then integrated and presented through psychological and pedagogical approaches to achieve educational goals, namely as good citizens.

- Edi Susrianto Indra Putra. Universitas Islam Indragiri. Email: ediunisi1971@gmail.com.

- Ahmad. Universitas ahmadunisitbh@gmail.com.

- Khairuddin. Universitas Islam Indragiri. Email: khairuddin921@gmail.com.

- Hasnawati, STAI Auliaurrasyidin Tembilahan. Email hasnawati@stai-stai-tbh@ac.id.

- Ferdinan. STAI Auliaurrasyidin Tembilahan. Email : ferdinan@staitbh.ac.id.
In line with the understanding of social studies above [2], [3], states that, basically social studies teaching with regard to human life involves all behaviors and needs. Social studies deals with the way humans use business to meet their material needs, meet their cultural needs. Utilization of existing resources on the surface of the earth, regulating its welfare and government and so on and preserving the lives of human society. In other words, the IPS examines and examines the system of human life on the surface of the earth. Social studies basically refers to two notions, namely Social Sciences education which is more inclined as an academic curriculum and introduction to the social environment called Social Knowledge Education. This approach applies when viewed from the level of education or level of education. Based on the teaching function at school, Social Sciences consists of Social Sciences and Social Studies. Education Social sciences (social science) are developed in academic curricula or disciplinary curricula at the secondary school level. Such a curriculum will use disciplines as labeling subjects and curriculum objectives are very closely related to the objectives of scientific disciplines. Whereas Social Studies Education (social studies) was developed for basic education levels. In this case the main focus of IPS is the study of the relationship between humans. Thus, to achieve harmony and harmony in life in the community, knowledge, skills and attitudes are formed through social studies education [4], [5]. The difference between Social Science Education and Social Studies Education on the other hand is not a fundamental or principle difference, but only a gradual difference, where social sciences are systematically organized and built through planned scientific investigations, whereas Social Studies education (social studies) consists of selected materials that have been simplified and organized psychologically and scientifically for the purposes of educational purposes. The difference between social sciences and social sciences Social studies (social studies) can at least be viewed in terms of four aspects, namely in terms of the object of study, in terms of its approach, in terms of its scope, and in terms of its framework [6]. Social studies education as "synthetict disciplines" seeks to integrate various concepts of education and social sciences, educational goals, and social problems that exist in society, so that it becomes an independent field of study. 
[7] grouped them into three parts, namely; (1) Social studies education as a Citizenship approach; (2) Social studies education as a concept and generalization approach that exists in the social sciences; and (3) Social studies education, whose approach absorbs and develops educational materials from social life. On the other hand, [8] grouped social studies into three traditions, namely; "(1) Social studies are taught as citizenship transmission, (2) Social studies are taught as social science, and (3) Social studies are taught as reflective inquiry". Social studies education as "citizenship transmission" relates to efforts to instill knowledge, attitudes, and values of student behavior that must be in accordance with the values and norms of the nation's culture. In this context, social studies education must be able to foster a love of regional cultural values as aspects of national cultural development and this cultural wealth the students are. Students will become good citizens if they can understand and apply the concepts and methods of the social sciences.

\section{ENVIRONMENT AS A SOURCE OF LEARNING}

Social studies education as a reflective inquiry aims to develop broader and deeper analytical skills of various factual problems that occur in everyday life in society. Students are trained to make decisions and problem solving from social problems using reflective thinking steps, namely; (1) identifying and defining problems, (2) formulating hypotheses, (3) elaborating the logical implications of hypotheses, (4) testing hypotheses, and (5) drawing conclusions. Barr's opinion, [9] above is in line with [1] which states that the main purpose of Social Sciences Education is to, "... help young people develop the ability to make informed and reasoned decisions for public good as citizens of a culturally diverse, democratic society in an interdependent world. Whereas [9] suggested that the main objectives of Social Sciences Education are as follows; "The main goal of the social studies should be to help students develop the ability to make rational decisions and to act intelligently ... The social studies program should help students gain proficiency in inquiry, valuing, and decision making skills". Meanwhile [10] argues that the purpose of Social Education is for students to get to know other people around them, adjust to their environment, and develop culture, arts, dance, traditional, regional, national traditional music, regional customs and so on.must be transmitted to the next generation in the education process. Social studies education as a social science is based on its purpose which seeks to develop the ability to think critically in accordance with the concepts contained in the social sciences, so as to be responsive to social phenomena that occur in the midst of society, especially in environments where The opinion above can be concluded that the purpose of Social Studies Education is to foster Indonesian citizens to become good citizens, who have social sensitivity and responsibility, have a democratic spirit, are able to respect ethnic, cultural and religious differences, think critically, creatively and are able to solve problems social problems and participate in the lives of local, national and global communities. Humans as social beings, not only interact with each other, but also with various organisms that exist in the surrounding environment. The environment has a very important life-supporting function, therefore its management and development is directed at maintaining its existence in a dynamic balance through various efforts to protect and preserve the environment. Human relations with the environment can not be separated, mutual need, and interdependence. Humans affect the environment, on the contrary humans are also influenced by the surrounding environment. According to [5] the relationship between humans and the environment can be grouped into four stages, namely; (1) when human civilization was still simple, human life was influenced by the environment; (2) the development of Science and Technology (Science and Technology) causes humans to explore the environment (humans affect the environment); (3) human and environment subsequent developments influence each other with the mediation of culture; and (4) the relationship between humans and the environment is increasingly complex in line with the development of Science and Technology. Social studies aims at developing good citizens, familiar with all elements of the environment, are wise and prudent in fostering relationships, exploring, exploiting, conserving, and develop various forms of existing environmental or cultural elements. Normally, each individual has a basic potential that develops and can be developed. The basic potential possessed by humans includes: interest (sense of interest), curiosity (sense of curiousity), impulse to prove (sense of reality), impulse to investigate (sense of inquiry), and impulse to find themselves (sense of discovery) [4]. Basically the objectives of social studies education must touch on aspects of behavior, attitudes, skills and knowledge about people's lives. In line with the tendency to increase various social problems in the community, Social Studies education must be able to play an active role in preparing students to be able to solve sharing social problems. With the reflective inquiry approach, students are expected to be able to develop a broader and deeper analysis of the factual problems that occur in everyday life in society. The condition of Indonesia's diverse society, which consists of various ethnic groups and a variety of customs and cultures, is often exposed to various social conflicts. That requires citizens who have strong personal characteristics who can live functionally in the current era of globalization. Then the reflective inquiry approach model is needed to solve the social problem. Regarding the ability of students to solve social problems, [10] argue, "The critical question put now to the reader is, what is happening in your classroom, your school, your district, and your state others should know about and which, if they knew about it, would help build public and professional anthusiasm for the social studies? " Basically social capital concerns behavior, norms, values, and social networks that develop in communities that live in a certain physical environment, including migration and adaptation of Banjar people in Indragiri Hilir Regency. Thus, in the theoretical framework of this research, the migration and adaptation events of the Banjar people are one of the determinants in the development of social capital. That is, in the event of migration and adaptation there is human behavior in interacting and building relationships with others. Social studies education needs to be developed continuously, dynamically, and epistemologically. According to [11] education and teaching of social science are able to identify patterns that connect humans with events, with places, with the past and future in an integrated manner experienced by humans in their world. On that basis, social studies education needs to be developed in a sustainable, dynamic, and epistemological way. 


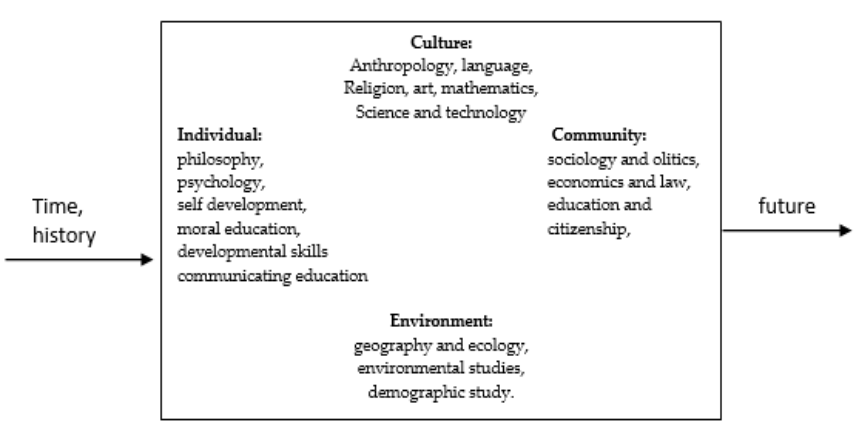

Figure 1

Model of contribution to social studies education

From the picture above it can be concluded that Social Sciences Education seeks to integrate learning materials from various branches of social science disciplines in an interdisciplinary manner and relate them to everyday problems [12]. asserted that social studies education has a special mission in developing the ability of young people so that they can utilize their physical and social strengths in facing their life problems. Therefore IPS education is aimed at the needs of the wider community as an effort to develop the personality of each individual. So the family, school and community environment is obliged to pass on these noble values to students, as well as the state through its concepts and ideas can motivate its citizens to be able to adapt, integrate, and participate in analyzing, making decisions, and solving various issues and problems social being faced by the environment. Basically, the goal of social studies education must be able to touch the aspects of behavior, attitudes, and social skills of the community itself. The development of a body of knowledge Social studies education must be oriented to the development of values, problem solving, and increasing community participation in solving social problems that are currently being discussed [13]. From the various opinions above, it can be concluded that the purpose of Social Studies Education is to foster Indonesian citizens to become good citizens, who have social sensitivity and responsibility, have a democratic spirit, are able to respect ethnic, cultural and religious differences, think critically, creatively and are able to solve social issues and participate in the lives of local, national and global communities. Education as a form of inheritance of cultural values, has a function of socialization and selection. Socialization in education includes aspects of values, cognition, and motor skills. Through the socialization of cultural values that are owned by the community, they can be transformed into values that are internalized or internalized by citizens in the form of cultural systems, social systems, and personality systems. Cultural systems contain values, norms, knowledge and beliefs or shared life beliefs. The social system contains a role structure that is the behavior that is expected to be done by someone in accordance with their social status. Whereas in personality systems, individuals have needs that are born or formed during the process of socialization for themselves. In accordance with the objectives of Social Sciences Education, which is to form good citizen behavior and be able to adapt to the environmental conditions of the community where it is located. Cultural values, customs, social participation and social networks, these factors can be developed and developed in the midst of society through social studies education. The contents of social studies education which are "synthetic disciplines", which consist of history, geography, economics, sociology, anthropology, citizenship and state administration education, are very relevant for studying and analyzing social values that grow and develop in the midst of Banjar society. The field of study of IPS education is so broad, not only with regard to human life that involves all of its behavior and needs, but IPS also deals with the way humans use business to meet material needs, meet their cultural needs. Utilization of existing resources on the surface of the earth, regulating welfare, how humans adapt to the surrounding environment, as well as ways humans maintain their lives in the midst of society, that is the nature learned in social studies teaching. As a "synthetic discipline", social studies education seeks to integrate various concepts of education and social sciences, educational goals, and social problems that exist in society, so that it becomes an independent field of study. It is expected that the development of social studies education in the form of "reflective inquiry", which seeks to develop analytical skills of factual problems that occur in everyday life in the community can be implemented in social studies learning models so that the main mission of social studies is to educate students to become citizens who are aware and responsible take responsibility and actively participate in the midst of society[14]. Integrating local cultural values in social studies education in the opinion of the writer is very necessary. Because basically the focus of social studies learning is the community. So it is very natural that in the social studies learning process the teachers in schools raise the regional culture that is owned by the community as part of the subject matter being taught. Through these efforts students are expected to get to know their area which in the end is expected to grow a sense of pride as part of citizens and can utilize regional cultural wealth as social capital in living life as citizens, both in local, national and global environments. This process is needed so that students can be more down to earth and understand the environmental conditions in which they grow and develop, because basically they cannot escape from the environment in which they grow and develop. The observations in the field show that social studies teachers tend to only deliver learning material according to what is contained in textbooks. Various research results have shown that social studies teaching is still oriented and laden with scientific development which is only theoretical and conceptual, and has not yet utilized the surrounding community environment as a source of learning.

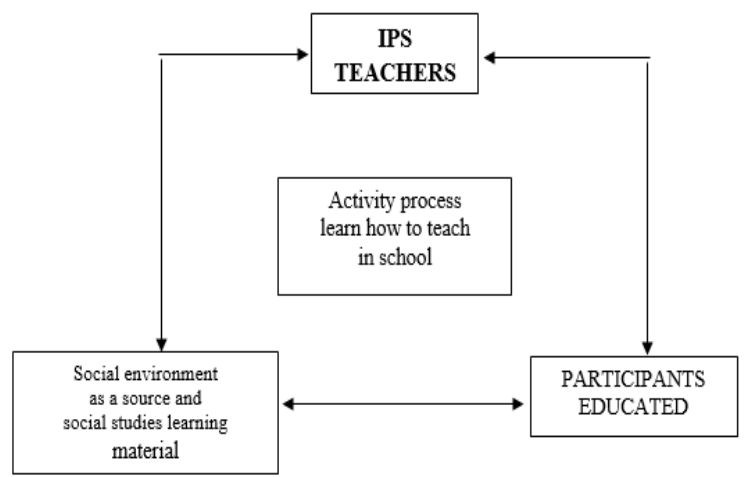

Figure 2 


\section{Environment as a Learning Resource for Social Sciences Education}

\section{CONCLUSION}

Social studies education not only emphasizes the development of cognitive aspects such as the ability to master concepts or theories of social sciences, the ability to think critically and analytically, or master social skills, but also can develop affective aspects of students which include the development of students' attitudes, values and morals. The reflective inquiry approach will encouraging students to use more critical and creative thinking to solve social problems and participate more actively in the community. Based on some of the views above, the use of the environment as a source of learning in social studies teaching has a very central function and is essential for the development and achievement of social studies education objectives at the school level. So that social studies learning that is characterized by meaningful, integrative, value-based, challenging, and active can be realized. Material about local content is rarely studied, although the competency standards contained in the curriculum make it possible to integrate local content material into learning activities. This is because teachers assume that the process of integrating material on local content will only take time and cause curriculum demands to be unreachable. In addition, social studies teachers assume that the process of introducing local content is not the responsibility of IPS education, but also the responsibility of local content subjects that have existed so far. This causes the social studies learning process at the level of schooling is only directed at cognitive development (transfer of knowledge) and and very less in the affective domain, thus making students less developed their thinking power. This condition causes students to be more inclined to memorize the material and concepts contained in textbooks only and are reluctant to develop critical thinking patterns. In that case one of the objectives of social studies education is to encourage students to think critically because the various issues raised in social studies learning are problems actual that occurs in the midst of society, including those related to the cultural value order of society.

\section{REFERENCES}

[1] Banks, J. A. (1990). Teaching Ethnic Studies: Concepts and Strategies. National ouncil for Social Studies.

[2] Banks, J. A. (1977). Strategic Teaching for Social Studies, Inqury, Valuing, and Decion Making. New York \& London: Longman.

[3] Barr, R., Barth, J. L and Shermis, S. S. (1978). The Nature of Social Studies. Palm Spring California: ETC Publication.

[4] Hasan, S. H. (1996). Social Sciences Education. Jakarta: Education Workforce Education Project Director General of the Ministry of Education and Culture.

[5] Jarolimek, J. (1977). Social Studies in Elementary Education. New York: Macmillan Publishing Company.

[6] Kamarga, H. (1994). The Concept of Social Sciences in Elementary Curriculum and Its Implementation in Schools. Thesis. IKIP Bandung Postgraduate Program. Unpublished.

[7] Kartidirdjo, S, et.al. (1975). Indonesian National History Volume V. Jakarta: Ministry of Education and Culture.

[8] NCSS. (1994). Curriculum Standars for Social Studies. Washington DC.

[9] Parker, W and Jarolimek, J. (1984). Citizenship and the Critical
Role of Social Studies. Washington, D.C: National Council fot the Social Studies.

[10] Somantri, N. (2001). Initiating the Renewal of Social Sciences Education. Bandung: Rosdakarya.

[11] Sumaatmadja, N. (1996). Humans in the context of Social Culture and the Environment. Bandung: Alfabeta.

[12] Sumaatmadja, N. (2002). Humane Humanity Education. Bandung: Alfabeta.

[13] Wiriaatmadja, R. (2002). Historical Education in Indonesia; Local, National and Global Perspectives. Bandung: Historia Utama.

[14] L. T. Muharlisiani et al., "Public Relations Management Through Management By Objective," vol. 8, no. 10, pp. 1993-1997, 2019. 